\title{
From Social Democracy back to No Ideology? - The Scottish National Party and Ideological Change in a Multi-level Electoral Setting
}

\author{
Peter Lynch
}

\section{Accepted for publication in Regional \& Federal Studies published by Taylor and Francis}

\section{Introduction}

Nationalist and regionalist parties have often been characterised as ideologically heterogeneous (Hix and Lord, 1997; De Winter and Türsan, 1998). This situation makes regionalist parties difficult to classify in conventional left-right terms though viewing these parties as an ideological family is to misunderstand their role and significance. Ideological profile can be understood as a secondary characteristic of regionalist parties, as opposed to their primary characteristic of support for selfgovernment - the core business of autonomy (De Winter, 1998, 208-9): which in itself contains a variety of constitutional options to reorganise the territorial distribution of power within a state (Rokkan and Urwin, 1983). However, though ideological positioning may be a secondary characteristic, most regionalist parties have adopted an ideology - in the SNP's case social democracy. As will be explained below, the reasons for adopting an ideology in itself, in addition to a particular ideology, are complex. For the SNP, the ideological position of elites, the policy preferences of the party's membership and the adoption of an electoral strategy to challenge a dominant political party in the region (Labour) were all influential. The adoption of an ideological position was not always uncontroversial but became easier due to party system change (the electoral decline of the Conservatives in Scotland from the 1960s), as the SNP came to focus much of its attention on Labour as its primary competitor. This strategy became successful in the 1980s and 1990s as voters began to recognise the SNP as a left of centre party, with quite similar policy preferences to Labour.

However, in the period following the SNP's ideological consolidation in the 1990s, the party faced a changing political environment as Labour's catch-all strategy 
(involving policy triangulation with the Conservatives) become very successful in accessing a broader spectrum of voters in Scotland (Saren and McCormick, 2004). In addition, new parties such as the Scottish Socialists and Greens emerged to become competitive at Scottish elections and the new electoral system for the Scottish Parliament provided multiple competitors and challenges to seat targeting, which placed obstacles in the way of the SNP's goal of becoming a party of government. In essence, the SNP was faced with adapting to party system change as well as multilevel elections in a short period of time, accompanied by the creation of the Scottish parliament in 1999. Specifically, this paper will argue that, whilst the SNP eventually settled into a consensual mode regarding its ideological position, ideology has become less important to the SNP (and to the electorate) and the party has ceased to stress its ideological position in explicit terms. Thus in recent times, the SNP has moved from identifying itself with the social democratic mainstream in the mid-1990s to de-emphasising its social democracy and adopting policies across the left-right spectrum to compete with different parties and especially with New Labour. However, this is not merely a result of changes in party strategy and the party system but also due to the changing shape of the electorate and the policy similarities between the parties in period of ideological depolarisation, which facilitated the SNP's voter maximalisation efforts at the 2007 election.

The majority of this article will look at the issue of ideological change within the SNP in historical perspective, specifically the gradual emergence of ideological influences within the party and its move towards social democracy in phases from the early 1960s. However, before looking at ideological change, it will also focus on the contextual factors of adaptation to party system change and participation in multilevel electoral settings - as these are important considerations guiding the party's ideological development. In addition, the article will provide a brief assessment of the SNP's role in multi-level governance since its election victory in 2007 , especially to see whether office success has moderated the SNP's territorial goals.

\section{Adaptation to Party System Change}

Whilst the 1950s were the highpoint of two-party politics in Scotland (and in Britain), the 1960 s produced considerable party system change through the electoral 
emergence of the SNP, the re-emergence of the Liberals and decline of the Conservatives (see table 1). The two party system was challenged most notably by the rise of the SNP at the general elections of February and October 1974 in which it grew rapidly to $30.4 \%$ of the votes, pushing the Conservatives into third place and taking seats from the Tories. Following splits in the Labour Party in 1981 and the emergence of the Social Democratic Party, the two main parties faced another third party challenge in 1983, with the growth of the Liberal-SDP Alliance to third place and $24.5 \%$ of the vote. And, significantly, this party also won seats from the Conservatives. Moreover, in the following decade, the Conservative's electoral decline plus a trend towards anti-Conservative voting became more common. In a number of seats, tactical voting by supporters of the SNP, Labour and Liberal parties reduced the number of Conservative seats from 21 to 10 in 1987 and then from 11 to 0 in 1997. Such developments markedly altered the ideological environment for all parties over time and the political opportunity structure for the SNP.

\begin{tabular}{|c|c|c|c|c|c|c|c|c|}
\hline \multirow[t]{2}{*}{ Year } & \multirow{2}{*}{\multicolumn{2}{|c|}{$\begin{array}{l}\text { Conservative } \\
\text { Votes Seats }\end{array}$}} & \multicolumn{2}{|c|}{ Labour } & \multicolumn{2}{|c|}{ Lib Dem } & \multicolumn{2}{|l|}{ SNP } \\
\hline & & & Votes & Seats & Votes & Seats & Votes & Seats \\
\hline 1945 & 41.1 & 27 & 49.4 & 40 & 5 & 0 & 1.2 & 0 \\
\hline 1950 & 44.8 & 32 & 46.2 & 32 & 6.6 & 2 & 0.4 & 0 \\
\hline 1951 & 48.6 & 35 & 47.9 & 35 & 2.7 & 1 & 0.3 & 0 \\
\hline 1955 & 50.1 & 36 & 46.7 & 34 & 1.9 & 1 & 0.5 & 0 \\
\hline 1959 & 47.2 & 31 & 46.7 & 38 & 4.1 & 1 & 0.5 & 0 \\
\hline 1964 & 40.6 & 24 & 48.7 & 43 & 7.6 & 4 & 2.4 & 0 \\
\hline 1966 & 37.7 & 20 & 49.9 & 46 & 6.8 & 5 & 5 & 0 \\
\hline 1970 & 38 & 23 & 44.5 & 44 & 5.5 & 3 & 11.4 & 1 \\
\hline $1974(\mathrm{~F})$ & 32.9 & 21 & 36.6 & 41 & 8 & 3 & 21.9 & 7 \\
\hline $1974(\mathrm{O})$ & 24.7 & 16 & 36.3 & 41 & 8.3 & 3 & 30.4 & 11 \\
\hline 1979 & 31.4 & 22 & 41.5 & 44 & 9 & 3 & 17.3 & 2 \\
\hline 1983 & 28.4 & 21 & 35.1 & 41 & 24.5 & 8 & 11.7 & 2 \\
\hline 1987 & 24 & 10 & 42.4 & 50 & 19.2 & 9 & 14 & 3 \\
\hline 1992 & 25.7 & 11 & 39 & 49 & 13.1 & 9 & 21.5 & 3 \\
\hline 1997 & 17.5 & 0 & 45.6 & 56 & 13 & 10 & 22.1 & 6 \\
\hline 2001 & 15.58 & 1 & 43.26 & 55 & 16.37 & 10 & 20.06 & 5 \\
\hline $2005^{*}$ & 15.8 & 1 & 38.9 & 40 & 22.6 & 11 & 17.6 & 6 \\
\hline
\end{tabular}


Of course, whilst the Conservatives declined and third parties emerged, the one constant in the electoral picture was Labour, which managed to maintain its position as Scotland's leading party at every national election from 1964 onwards (it also won more seats than the Tories in 1959 in Scotland) until 2007. Labour's electoral performance was strong and its level of representation aided by the first past the post electoral system. However, this situation changed with devolution in 1999 (see table 2). The electoral system for Scottish elections (AMS using first past the post and regional list PR) made Labour a minority in the Scottish Parliament and reliant upon a coalition partner to enter government (hence two Labour-Liberal Democrat coalition governments from 1999-2007). In addition, the electoral system plus changes in party support transformed the SNP from a marginal party at UK elections to the main opposition party in the Scottish Parliament - recasting Scottish politics as a contest between the SNP and Labour. This new reality manifested itself most clearly when the SNP came first in the Scottish elections in 2007, relegated Labour - marginally into second place in seats and votes - and entered government for the first time.

Table 2. Scottish Election Results (constituency votes plus total seat count), 19992007

\begin{tabular}{|c|c|c|c|c|c|c|c|c|c|c|}
\hline & \multicolumn{3}{|c|}{ Conservative } & \multicolumn{3}{|c|}{ Lib Dem } & \multicolumn{2}{|l|}{ SNP } & \multicolumn{2}{|c|}{ Others } \\
\hline & Votes & Seats & Votes & Seats & Votes & Seats & Votes & Seats & Votes & Seats \\
\hline 1999 & 15.5 & 18 & 38.8 & 56 & 14.2 & 17 & 28.7 & 35 & 2.8 & 3 \\
\hline 2003 & 16.6 & 18 & 34.6 & 50 & 15.4 & 17 & 23.8 & 27 & 9.8 & 17 \\
\hline 2007 & 16.6 & 17 & 32 & 46 & 16 & 16 & 32.9 & 47 & 2.5 & 3 \\
\hline
\end{tabular}

The emergence of the SNP as a serious competitor to Labour was not the only party system change to come with devolution. The new electoral system also saw the success of new political actors in gaining institutional representation in Scotland. The first Scottish elections in 1999 saw 3 MSPs from outwith the main parties - one independent, one Green and one from the Scottish Socialist Party. This development 
became more pronounced in 2003, when there was considerable voter experimentation outside the four traditional parties, especially on the regional list vote. Independents and small parties picked up $9.8 \%$ of the constituency vote and 2 seats as well as $22.3 \%$ of vote and 15 seats on the regional list (with the SNP as one of the main losers). This outcome was not repeated at the 2007 election. At that election, only 2 Green MSPs and one independent were elected and the SNP's electoral success saw it pick up a large number of seats on the regional list at the expense of the small parties. The party's electoral success can be attributed to a specific regional list strategy based around the party leader, Alex Salmond, the spectacular implosion of the Scottish Socialist Party and the SNP's success in casting the election as a two-party contest against Labour and effectively projecting itself as an alternative government, which helped concentrate voters' minds to cast protest votes or votes for change in the direction of the SNP. Ideological factors were not unimportant in 2007 and will be explored in great detail later in the article.

\section{Multilevel Elections and Multilevel Governance}

The SNP has had a differentiated level of performance in multilevel electoral settings - though a pronounced capacity to perform better at some electoral levels than others. The party's performance in different electoral settings can be divided into four distinct time periods. First, from 1934 into the mid-1960s, the SNP was an extremely marginal electoral actor, meaning it seldom contested seats at UK general elections or in local elections. Second, from the 1960s to 1970s, the SNP appeared a much more serious political force, in contesting Westminster elections (most spectacularly in the two general elections in 1974) and in fighting and winning seats in local councils, especially at local and regional council elections in 1977 and 1978 (Lynch 2001: 212). Third, the advent of direct elections to the European Parliament from 1979 onwards provided a new electoral setting for the SNP and one in which it managed to outperform its UK election total. In 1979, the SNP's European result was 19.4\% compared to $17.3 \%$ for Westminster. This gap increased in 1984 (17.8\% to $11.4 \%$ ), 1989 (25.6\% to $14 \%$ ) and 1994 (32.6\% to $21.5 \%)$, before devolution added a new multilevel setting in 1999. The SNP's European performances were accompanied by policy development in relation to the EU and to the reshaping of the party's central goal of Scottish independence to take account of the relaunch of the EU after the 
Single European Act. Fourth, the first elections to the Scottish Parliament in 1999 saw a similar picture to that of Europe when compared to the party's performance at UK elections (which John Curtice has referred to as the 'Holyrood gap'), with the SNP winning $28.7 \%$ of the constituency vote in 1999, followed by $23.7 \%$ in 2003 and then $32.9 \%$ in 2007 . However, this multi-level setting was significantly different in that the elections made the SNP the principle opposition party and alternative government in Scotland - something not possible at Westminster or the European Parliament - and led the party into minority government in 2007. Simultaneously, the adoption of proportional representation for local elections in 2007 helped the SNP to become the biggest party in Scottish local government with the largest number of councillors and a governing role in 13 of Scotland's 32 local authorities. Therefore the new institutional setting of the Scottish Parliament and electoral system changes to the local setting transformed the SNP's position.

Success in the 2007 Scottish election has had two linked effects, on the SNP and on its main political competitors. First, the SNP's independence strategy post-devolution relied upon gaining power in the Scottish government and then using office as a mechanism to hold an independence referendum. The party formed a minority government in May 2007, published a white paper on Scotland's constitutional options in 2007 (Scottish Government 2007), launched a consultation process on Scotland's constitutional future, ${ }^{\mathrm{i}}$ and planned an independence referendum for 2010. Second, the SNP's success generated policy co-operation between Labour, Liberal Democrats and the Conservatives over amending the devolution settlement to grant more autonomy to the Scottish government. These parties launched a Scottish Constitutional Commission in April 2008 to examine proposals for more policy and taxation powers for Scotland. ${ }^{\text {ii }}$

\section{A Brief Guide to Ideology in the SNP}

The SNP did not have a clear ideological position until the 1980 s - the period when the party sought to present itself as a left-of-centre in explicit terms through policy and party publicity. Before then, there were some ideological traditions within the party - such as social democracy emerging in the 1960s and 1970s - but the SNP did not seek to present itself as an ideological party. As will be discussed below, the SNP 
was not born with an ideology in 1934, but for an important part of its history it was seen to be governed by a 'ruling myth' that it was neither of the left or the right but constituted a new politics that sought to put Scotland first (Brand, 1990: 28). For example, party propaganda in the 1960s stated that:

The National Party stands for the nation; all sections, all people in it; welded in a common purpose; devoted, dedicated to the social and economic improvement of all..........Instead of asking us to put our own country first, the Labour, Tory and Liberal parties divide Scotland against herself. These parties ask us Scots to give our prime loyalty to their outdated Anglo-Scottish sectional and class interests (SNP 1966: 5).

Party elites and members were keen to promote a unique place for the SNP within the electoral marketplace, rather than advance the same ideological position as the Unionist parties of Conservative and Labour. The myth was particularly potent in the 1960s and 1970s. At the two general elections of 1974 (February and October) eight of the SNP's eleven seats had been won from the Conservatives. This situation reinforced the ruling myth by making it appear as if the SNP had won support from Conservative defectors and that keeping these new voters within the SNP necessitated a neutral stance on ideology and class. However, what was clear at the time and subsequently, was that the SNP victories in Conservative seats were a result of the party's success in attracting an anti-Conservative coalition of former Labour and Liberal voters to help oust sitting Tories in seats such as Moray and Nairn, Galloway and Upper Nithsdale and Aberdeenshire East (Lynch, 2002: 132). However, convincing sitting MPs that this was the case proved next to impossible and their perceptions and actions within the House of Commons did not help the SNP to project a clear political identity in relation to ideology.

However, the ideological debate within the party was not merely about ideology and it would be wrong to suggest that the party was characterised by an ongoing conflict between right and left. In fact, the debate was more about the SNP being distinct - a national movement with new politics - rather than another UK-based party of sectional interests and also one that needed to be an all-Scotland movement. It was also influenced by the 'independence nothing less' view within the party, especially 
evident within the old guard from the 1950s, which saw detailed policies as a distraction from independence (Brand, 1990: 25). This itself was a reflection of divisions within the party about whether it should exist as a national movement for independence that contained all shades of political opinion or a political party with detailed policies (Mitchell, 1990).

Such internal complexities were obstacles that prevented the SNP from adopting a clear ideological position for much of its history, but it did not last forever. At both of the general elections of 1974 - at the SNP's electoral peak - the SNP election manifesto had proclaimed the SNP as a social democratic party and proposed a range of social democratic policies (Lynch, 2002: 133). There was even an aborted attempt to change the SNP's name to the Scottish National Party (Social Democrats) at the 1975 annual conference. ${ }^{\text {iii }}$ Whilst the SNP faced ideological and strategic conflict in the post-1979 period - with the rise of the Socialist 79 group - these developments gave way to as clearer and less controversial ideological position. As early as 1982, SNP literature described the organisation as 'a moderate, centre-left party' (Brand, 1990: 27), leading to the more elegant statement that appeared on the SNP website in recent years that proclaimed the SNP as 'a democratic left-of-centre political party committed to Scottish Independence. It aims to create a just, caring and enterprising society by releasing Scotland's full potential as an independent nation in the mainstream of modern Europe. ${ }^{\text {iv }}$ However, arguably, this ideological position whilst recognised by voters - has become less important and effectively deemphasised by the SNP in the more ideologically fluid post-devolution period. This development will be dealt with at the close of the next section, which outlines the SNP's ideological development since its formation in 1934.

\section{From No Ideology to Social Democracy and Back Again? Five Phases in the SNP's Ideological Development}

It is possible to identify five distinct ideological phases in the life span of the SNP from the 1930s to the 2007, which demonstrate the SNP's transition from a nonideological position, to adopting social democracy and a centre-left perspective to entering a post-devolution period in which ideological considerations were less important: a fact shared by the party's competitors. These phases did not fall into 
strictly separate timescales but are overlapping. For example, some such as the nonideological centrist and social democratic period overlap quite strongly in terms of issues and personnel. However, the different phases are intended as a guide to the main events and developments - and especially political contexts - that gave rise to ideological change within the SNP. They are also clearly indicative of adaptation to a changing party system and to highly competitive multi-level elections.

SNP Formation In 1934 the SNP's formation saw a number of different ideological perspectives and existing parties merge to establish the new party but provided it with no clear position on the left-right scale. Though political parties can be understood as organisations that are established by and attract people with similar political opinions (Ware, 1996: 4), in the case of the SNP, this opinion involved the importance of Scottish self-government rather than a political ideology. The SNP's founders were united over self-government in principle, though not its exact nature (the differing options of devolution, home rule and independence) or the best strategic means to achieve self-government. The Scottish National Party was formed through the amalgamation of the National Party for Scotland (NPS) and the Scottish Party. Each of these merging parties had different ideological perspectives. Whilst the NPS was left of centre, the Scottish Party formed in 1932 was more right-wing in terms of policy and membership and, to all extents and purposes, existed as a party of notables from the Conservatives and Liberals rather than an organisation with a broad membership (Brand, 1978: 216-7). Thus, the SNP initially contained contrasting ideological forces within its ranks, at the level of the party's élite and its membership. The internal distribution of ideological views necessitated some compromises about the party's programme that blurred its distinctiveness. However, the real divisions between the NPS and Scottish Party were about attitudes to independence and devolution and to contesting elections rather than about ideology (Finlay, 1994). Moreover, ideological debate within both the NPS and the Scottish Party seems to have been limited. For example, even though the National Party of Scotland was more left wing than the Scottish Party, little serious policy work was done by the NPS especially in relation to the economy. The central concern of the NPS, not surprisingly, was the issue of independence: an obvious fact that influenced the content of SNP debates and policy too. 
Centrism in the 1930s to 1960s In the period from the 1930s to the 1960s the SNP presented itself as a moderate centrist party, attempting to stand aside from class conflict and seeking to win electoral support as a 'third party' alternative to the Liberals and profit from dissatisfaction with the two main parties. Whilst clear policies were thin on the ground at the time of the party's creation, they were in place by 1938 and restated in clearer form in 1946, though not in great detail. However, the real issues that exercised the SNP in this period were: attitudes to contesting elections versus pressurising other parties to take self-government seriously; alliances and cooperation with parties such as the Liberals; the SNP's position on neutrality, entry into the war and the issue of conscription; and dual membership between the SNP and other parties (Brand, 1978: 231-2; Finlay, 1994). After the war ended, the party developed a more serious interest in policy, organisation and membership, with an Aims and Policy statement in 1946 and new party constitution in 1948. Policy from 1946 was radical and redistributionist in relation to land and in favour of 'the diffusion of economic power', including the decentralisation of industries such as coal to include the involvement of local authorities and regional planning bodies to control industrial structure and development. ${ }^{\mathrm{v}}$ The document generally supported the status quo in relation to the economy and social policy, with its main emphasis being the transfer of power from UK to Scottish government rather than any transfer of power within Scotland. The decentralist ethos evident in the policy statement sat alongside support for state intervention in many areas. This latter policy may reflect the wartime orthodoxy of central planning and has existed within SNP policy for decades ever since. $^{\mathrm{vi}}$ However, what the policy statement certainly did not contain were commitments to the redistribution of wealth or anything resembling Socialist or Social democratic language or clear policy commitments. This is not to attempt to place it on the right however, because it didn't contain free market language or ideas either.

The political context in which the SNP found itself in the post-1945 period was not one that facilitated clear ideological choices for the party. Certainly, internally, the SNP was centrist and did not contain influential figures keen to move it to the left or right. However, the distribution of electoral support in Scotland made it difficult to provide a political logic for developing a clear profile. Three specific factors in relation to the party system in Scotland were important for the SNP and its placement 
in the left-right scale from the period from 1945 to 1962. First, the SNP was seeking and failing - to compete in a two-party system in which the Scottish Unionists (Conservatives) and Labour did not so much dominate post-war elections as monopolise them. In 1945 , the two main parties gained $88.7 \%$ of the vote, rising to $91 \%$ in $1950,96.5 \%$ in $1951,96.8 \%$ in 1955 before slipping back to $93.8 \%$ in 1959 . In these circumstances, there wasn't much of a third party vote to attract or much political logic in shaping the SNP as either left or right in ideological terms to challenge either Labour or the Unionists - the party had to try to challenge them both on the issue of self-government. Partisan dealignment in the 1960s altered this situation markedly to the SNP's benefit.

Second, the policy choices of the two main parties limited the space for the SNP in a period of consensus politics. The SNP, as well as any other third party, lacked a cutting edge in policy terms as the two big parties experienced substantial levels of electoral popularity through adopting similar policies with state intervention in a mixed economy, nationalisation, extensive public house-building programmes, etc. The SNP adopted similar policies and accepted much of the post-war consensus in relation to its policy programme, which further blurred any cutting edge. Moreover, though the issue of self-government found considerable expression in this period through the National Covenant campaign in the early 1950s, the issue did not feed into party politics in the way of votes for the SNP. It was not until the decline of the Scottish economy in the late 1950s that the party was able to promote selfgovernment and the Scottish dimension to policy as viable political alternatives: which partly explains the SNP's emergence in industrial Scotland in the 1960s.

Third, whilst there was very little political space in which to operate between the two main parties, there was a formerly Liberal electorate available given the organisational decline of the Liberals across Scotland. It was this electorate that the SNP sought to attract. For instance, the Liberals only contested five seats out of seventy-one at the 1955 general election, meaning that Liberal voters didn't actually have a Liberal candidate to vote for (though some could vote for National Liberals in alliance with the Scottish Unionists). In the 1950s this electorate was small but in the 1960s it grew with the dealignment of the party system evident in the growing vote of both the Liberals and SNP in the 1964 and 1966 general elections. ${ }^{\text {vii }}$ In addition, the 
idea of dealignment itself - in class and electoral terms - caused difficulties for the adoption of an ideological identity too. What would be the point of adopting a clear ideological profile and position on the class divide, just as those divisions were breaking down?

\section{The Rise of Social Democracy A social democratic tradition began to emerge} within the SNP in the 1960s but only became explicit in the 1970s. This development had a number of origins. First, internally, the SNP recruited a large number of centreleft members, may of whom came to occupy prominent positions within the party's leadership structures and serve as parliamentary candidates. In the 1960s, the party grew in urban, industrial Scotland and experienced an influx of social democrats from the Labour Party, the trade unions and the Campaign for Nuclear Disarmament (Mitchell, 1996: 208). Billy Wolfe's performance at the West Lothian by-election in 1962 was an example of this phenomenon (Wolfe 1973). This process continued in the 1970s and aided the emergence of a younger generation of Socialists who formed the 79 Group and became prominent in the SNP in the early 1980s. Some members joined the SNP from the defunct Scottish Labour Party in 1979 (Drucker, 1978), whilst others joined from Labour over issues such as the poll tax in the late 1980s. viii Generational change was also important in terms of new members and the political retirement of older generations. As the older generation of traditionalists within the SNP retired or became less active they were unable to resist the policy preferences of the new more left-wing generations that came into the SNP in the 1970s (Brand, 1990: 32).

Second, the Scottish party system had shifted in the late 1950 s to become more obviously Labour in terms of electoral support and representation. Labour won 38 seats in 1959 on $46.7 \%$, even though the Conservatives gained marginally more votes. From then on however, Labour led the polls at every general election in Scotland with a clear majority of the seats (usually more than 40 out of 72 ) and the Conservative's period of competitiveness with Labour was over. Targeting Labour through emphasising left of centre policies and values was therefore electorally logical as well as tying in with the ideological preferences of many new members in the 1960s. The SNP therefore followed the political logic of the times in terms of competing in a centre-left country as well as its own internal distribution of ideological opinion. 
Learning this lesson took time however. Some within the party argued that the SNP was winning significant numbers of votes from the Conservatives in the 1960s and 1970s and should avoid adopting an ideological position. The party won seats and votes from the Conservatives, who appeared in serious decline, so fudging the SNP's ideological position was seen to be advantageous. However, given the dominant position of the Labour Party and the seemingly inexorable decline of the anti-Home Rule Conservatives, there was little prospect of the SNP actually aligning with the ideological right.

The rise in social democratic ideas was not just driven by new members and electoral strategy it was also driven by policymaking changes within the SNP organisation. First, at an expanded party headquarters, there was much more focus on producing detailed policies which could be used for publicity purposes, candidate briefings, press releases, election literature, etc. Some of this work was undertaken by Billy Wolfe as a part-time research director, producing economic material in particular through the medium of the Social and Economic Inquiry Society of Scotland: a group of SNP supporters from the business and academic community who provided policy advice and briefings for the SNP. The group assisted in hosting a series of seminars on energy, science, land use, agriculture and the Scottish economy (Wolfe, 1973: 64). The level of policy debate and expertise rose as a result. Moreover, Billy Wolfe's election as party leader in 1969 was seen as an endorsement of a policy-focused SNP (Miller, 1981: 47), as opposed to one that would stay neutral on policy (and ideology) until there was a Scottish parliament in place to make detailed policy.

Second, the existing range of SNP policies was gathered together into an accessible brochure - SNP \& You - which was first drafted in 1964 and distributed from 1966 onwards. The document adopted Wolfe's amended name for the SNP - SNP: The Democratic Party - in order to emphasis democracy and participation rather than nationalism. The document contained contained commitments to full employment, government intervention in fuel, power and transport, a state bank to guide economic development, encouragement of co-operatives and credit unions, extensive housebuilding by central and local government, pensions adjusted to cost of living, a minimum wage and an improved national health service. What this all adds up to is a party with centre-left policies, even though it pitched itself as a new politics party 
beyond class politics during this decade (SNP, 1966). Third, the reorganisation of the SNP to create a National Assembly responsible for policy debates increased the depth and width of SNP policies from 1968 onwards. National Assembly created a large number of specialist policy committees that began to generate detailed statements across all areas of policy, with lengthy resolutions on employment dealing with the minimum wage, industrial democracy, profit sharing, collective bargaining, trade union rights, the closed shop, pensions, equal pay, etc. a the 1969 party conference. ${ }^{\text {ix }}$ Resolutions of similar length and detail dealt with forestry, welfare and community services and industrial development (SNP, 1969). Such institutional developments and processes are part of the reason for the perception that SNP policies became social democratic in the 1970s 'by accident' rather than simply design (Mitchell, 1996: 207).

Third, policies weren't just adopted in order to compete with electoral opponents but to provide a vision of what an independent Scotland would look like. ${ }^{\mathrm{x}}$ SNP policies for post-independence Scotland assumed a key role for the state. This resulted from prevailing economic views about government intervention that ran from the war economy of the 1940s through the period of consensus politics in Britain that was seen to exist until the late $1970 \mathrm{~s} .{ }^{\text {xi }}$ But, it also mirrored policies seen to be vital to construct and maintain an independent Scotland through central government intervention. Such policies were not mirror-image copies of the main parties though as there was a strong decentralist ethos within the SNP that was suspicious of big government (and of social democratic crisis, Maxwell, 1975). In addition, the post1979 period saw a significant recession in Scotland presided over by an unpopular Conservative administration instituting more free market policies: aligning with this type of ideological position was simply unthinkable for the SNP in this period given its existing policies. If the party adopted any position, it had to be on the centre-left and opposed to the Conservatives.

In addition, some policies adopted in the 1960s were recognisably on the left. SNP conference in 1961 expressed the party's opposition to the siting of the Polaris submarine base in Scotland. This policy was followed in 1963 by a motion opposed to nuclear weapons (Mitchell, 1996: 194): policy that has remained in place ever since and later followed by opposition to Scottish membership of NATO. Labour by 
contrast was unilateralist in 1960, but reversed its position in 1961: a change that brought some members into the SNP (and helped move the SNP to the left). The 1960s also saw the beginnings of the SNP's efforts to establish an industrial organisation and mobilise amongst trade unionists in Scotland. The Association of Scottish Nationalist Trade Unionists was formed in 1967-8 with the intention of assisting the SNP to organise amongst union members and develop some presence within the unions locally (Lynch, 2002: 133). Promoting the SNP amongst the trade union membership was seen to be an important part of attracting Labour voters to defect to the SNP, with a trade union strategy document adopted in $1974 .^{\text {xii }}$

How did the voters view such development? Miller's study of the October 1974 general election in Scotland found some evidence of voter perceptions of the political parties. For example, 37\% thought the SNP was closest to Labour in policy, compared to only $17 \%$ who thought the SNP close to the Conservatives, whilst $46 \%$ did not know (Miller 1981: 127). When it came to determining voters' second choice party, SNP voters divided fairly evenly between all three alternative parties: $31 \%$ chose the Conservatives as their second choice, 35\% chose Labour and 33\% chose the Liberals (Miller, 1981: 127). However, despite some progress in the direction of social democracy - not least emphasising it within party publicity - there was some dissatisfaction amongst new SNP members about the party's policies and ideological positioning. This development manifested itself after the 1979 devolution referendum and general election through the creation of the socialist 79 Group.

The 79 Group was the first organised ideological faction within the SNP. It emerged at a time of ideological polarisation in both Scottish and British politics, strongly influenced by the experience of Mrs Thatcher's Conservative government. The stated aims of the 79 Group were full independence, a Scottish republic and a socialist redistribution of power, income and wealth. ${ }^{\text {xiii }}$ However, the type of socialism the 79 Group had in mind was quite limited. Socialism was not defined or debated at any great length and the group's aim was largely to attack the old guard and the 'ruling myth' and target the Labour electorate. The 79 Group's critique of the SNP was straightforward though its solutions in terms of policy and strategy were limited. One 79 Group member described the SNP 'more as an apolitical party than a political one' in relation to ideology and policy. ${ }^{\text {xiv }}$ In essence, the group advanced little more than 
existing SNP policy, with a few additions, plus a strategy to move to the left (Brand, 1990: 26): however, significantly, it worked. Brand (1990) saw the 79 Group partly as a response to the SNP's experience during the 1970s, when it was still pilloried by Labour as being 'Tartan Tories'. New activists joined in the 1960s and 1970s and these members moved SNP policy and outlook to the left. Traditionalists who resisted a clear ideological profile for the SNP were in decline in terms of numbers and activism. This process of change explains why traditionalists within the SNP were able to use arguments about party unity to defeat and expel the 79 Group at annual national conferences from 1979 to 1982 . But, despite this evident success, ${ }^{\mathrm{xv}}$ some of the 79 Group's proposals were adopted anyway as the SNP declared itself as a centreleft party and involved itself in a series of industrial campaigns in the early 1980s. Brand (1990) also argued that the political context of the post-1979 period was important. The new Conservative government of Margaret Thatcher was not only completely opposed to Scottish self-government in any form, but instituted a series of economic policies that brought industrial crisis and recession to Scotland. Such policies led the SNP into a series of industrial campaigns in the early $1980 \mathrm{~s}^{\mathrm{xvi}}$ and such campaigning rolled forward to encompass SNP support for the miners' strike (Brand, 1990: 29) as well as opposition to the poll tax after 1987: each intended to outflank Labour and appeal to working class voters.

The Left-of Centre Consensus From the mid-1980s onwards, the SNP's political identity as a left-of-centre nationalist party was established in terms of both its policies and electoral support. After the period of conflict around the existence of the 79 Group, the party settled down to a period in which strategy rather than ideology were important. This involved civil disobedience against unemployment and the lack of self-government in the early 1980s, followed by a non-payment campaign against the poll tax in the late 1980s; modernising independence to take account of European integration; and debate over co-operation with its opponents to promote selfgovernment in the shape of the Scottish Constitutional Convention. Instead of debating ideology, the SNP promoted its policy stances as left of centre and sought to project a centre-left profile in party publicity and campaigning: especially after the clearly left-wing Alex Salmond became party leader in 1990. Salmond sought to make the SNP a credible alternative to Labour and thus attractive to Labour voters. This occurred in period in which the Nationalists were part of the anti-Conservative 
consensus in Scotland along with Labour and the Liberal Democrats, keen to oppose Conservative economic policy and also to promote Scottish self-government.

By the 1990s, many voters saw the SNP as similar to Labour and each party's electorate shared a large number of socio-economic and policy features (Brand, Mitchell and Surridge, 1994). Labour and SNP voters were most similar on the leftright continuum and when asked about party placement on the socialist-laissez-faire and the liberal-authoritarian dimensions, supporters of the two were inseparable and clearly distinguishable from the Conservatives (and from the Liberal Democrats on the socialist-laissez-faire dimension) (Paterson et al, 2001: 61). In 1997, more leftwing voters on the left-right continuum were more likely to vote Labour rather than SNP, but this was no longer the case in 1999 (Paterson, 2001: 63). Similarly at that time, there was a fall in voter images of Labour as a party that defends working class interests $-93 \%$ of the Scottish electorate thought (British) Labour looked after working class interests very or fairly closely in 1997 , which fell to $53 \%$ in 1999 . The figure for Scottish Labour was 66\% - the same level as the SNP (Paterson 2001: 58). In addition, Labour was seen to look after middle class interests more than working class interests. This changed reality helped the SNP to emerge as the second most popular party in Scotland in the late 1990s and to cast itself as the replacement party to Labour. When New Labour appeared on the scene in 1994, with its concern for middle England, the SNP focused its attention on 'mainstream Scotland' (Mitchell, 1996: 294) - promoting a moderate, centre-left identity that had broad appeal across Scotland.

The End of Ideology? In the period from 1999 onwards, the SNP's policy profile became more mixed and its centre-left profile was de-emphasised - evident in its manifesto commitments for the 2003 and 2007 Scottish elections and in relation to its programme in government. The success of New Labour in dominating the centre ground of politics from the mid-1990s was an instructive lesson for the SNP. Labour was seen to practice a strategy of triangulation towards its opponents - occupying some of their traditional ground whilst relocating Labour's position on its own issues. This strategy caused difficulties for the Conservatives, with Labour staking out new policies on the economy, immigration and law and order. In Scotland, such issues included land reform (Scottish new Labour 1999), which the SNP had been working 
on for a number of years through a special Land Commission. Labour made it more difficult for the SNP to stake out distinctive positions and, in time, the SNP learned this lesson and sought to produce policies that were eye-catching but also spanned the centre-ground of Scottish politics - with the important caveat that the centre ground in Scotland is perceived as a left of centre one. Thus in 2003 and 2007, the SNP sought strong policies on law and order issues, economic growth and business development (SNP, 2003, 2007), ${ }^{\text {xvii }}$ as well as a pronounced small government agenda in 2007 involving efficiency savings, a government reorganisation and a reduction in Quangos (SNP, 2007). In addition, the party was active in seeking support within the business community, building on the work of Business for Scotland, an organization established by SNP supporters in 1998. The strategy of this organization was to bolster arguments around the economics of independence through business supporters. Key members produced a new analysis of the Scottish economy based around the need for domestic business growth and fiscal autonomy in 2001-2 that was taken around the boardrooms of Scottish businesses. In addition, the organization helped generate high profile supporters of the SNP at the 2007 Scottish election who, in some cases, provided substantial donations to the party's election campaign. However, such pro-business policies co-exist with a strong commitment to the public sector. For instance, in government, the SNP cancel a Scottish government programme for a private prison at Bishopbriggs near Glasgow and to reform the Public Private Partnership programme to reduce private sector profits and produce more value for money for the public sector (Scottish Government 2007a).

However, it's not just Labour's reorientation that was influential for the SNP, but also the need to adapt to the complexity of a multi-party system combining FPTP and regional lists - in a period in which the political conflict was suddenly free from the anti-Conservative politics of the elections from 1979-97. Not only were the SNP faced with FPTP contests with a range of parties, but also faced the challenge of multi-party competition on the regional lists, whilst also trying to present the SNP as a responsible alternative party of government. In this sense, the party faced a range of difficulties as it was pulled in different directions. After the 2003 election reverse, there was pressure on the SNP leadership to turn to the left to recover support from the Greens and SSP - in contrast to its moderate manifesto, pro-business in 2003 that had sought to act as a programme for government. However, rather than change 
policy, the SNP changed leader - with Salmond's return in 2004. This change opened the door to a more successful and personalised regional list vote strategy - vote Alex Salmond for First Minister a the top of each regional ballot paper - that didn't focus on ideology at all but on personality. Similarly, there was little mention of the SNP's social democracy in the party's manifesto or campaigning, with much more emphasis on policies to improve the public sector and to generate economic growth. However, rather than arguing that this is an indication of the SNP abandoning social democracy, it's more likely that the party no longer feels the need to stress its ideological identity at a time of ideological convergence given that it has achieved its goal of narrowing the gap with Labour.

What seems to be observable now in terms of electoral behaviour has some parallels with the 1970s. Part of the SNP's success over time, rather than simply in 2007, can be related to class dealignment as the links between socio-economic status and voting have weakened and working and middle class voters have been more fluid in their electoral behaviour. This phenomenon was observable in the 1970s as well as more recently. Brand (1978: 146-7)) used data from the mid-1970s to determine the crossclass nature of SNP support and the party's challenge to notions of class voting. Though class voting still has some role in Scottish elections (Bennie et al, 1997), dealignment has occurred to provide opportunities for the SNP as well as a challenge for the other parties. Indeed, rather than focus on social class explanations of electoral behaviour, some recent studies have sought to employ the concept of valence politics to explain some of the reasons for the outcome of the 2007 Scottish election (Johns et al, 2007). Valence explanations focus on voter perceptions of a party's capacity to deliver its policy goals - rather than the detail of the policies themselves. This model was seen to have validity as it offered explanatory potential at a time in which there was ideological convergence between the main parties - witnessed by the closeness of the SNP and Labour - and class dealignment, explained in part through the fact that the working class has shrunk through social mobility (Paterson, 2006: 50-1). Similarly, in $2007,52.5 \%$ of voters did not identify with a political party, creating a more open electorate to appeal to through valence issues through positive campaigning. In this context, ideological or social class appeals are seen to be less relevant than party and leader images and the ability to use the constitutional issue 'to stand up for Scotland' (Johns et al, 2007: 6). Stressing issues, image and leadership 
over a consensual ideological position shared by other parties was therefore seen to be advantageous as well as an important adaptation to a changing party system and electorate.

\section{Office Success and the Multi-level Dimension}

The establishment of the devolved parliament in Edinburgh in 1999 created the primary arena for SNP activity, eclipsing both Westminster and the European Parliament. All the SNP's Westminster MPs became MSPs in 1999 with the party aiming at forming a government in Edinburgh rather than being a marginal presence at Westminster and in Brussels. The size of the SNP contingent in the Scottish Parliament, the fact that the bulk of its leadership was elected to this body and that it was the main opposition party all enhanced this arena above all others. The SNP was still active at Westminster, often in alliance with Plaid Cymru and in the European Parliament with the European Free Alliance and Greens, but Edinburgh and government office became the main focus of its activities. This situation increased in 2007, when government rather than just parliament were the main focus of its multilevel activities.

The SNP formed a minority government at Holyrood following the party's marginal victory at the 2007 Scottish election. Having faced the challenges of adaptation to a changing party system and electorate, the party is now faced with adapting to life in government and to its impact on its fundamental territorial goal of independence. The minority status of the SNP government has conditioned its performance in office. Though, the party achieved office through a co-operation agreement with the Greens, ${ }^{\text {xiii }}$ it has also been reliant upon its opponents for support on key issues trading policy commitments with the Conservatives on policing and business taxation in exchange for support for its budget and also seeking consensus with the Liberal Democrats over issues such as local taxation. The lack of fundamental divisions between the parties on some issues plus the SNP's flexibility were important here as discussed extensively above. However, governing has not been easy in relation to passing legislation or passing budgets, as each required careful management and compromise (Lynch and Elias 2009). 
Second, the minority status of the government has actually helped the SNP in relation to its territorial goal as it could promote independence and the notion of an independence referendum in office, instead of being forced to compromise on independence through coalition negotiations. The SNP published a government white paper on Scotland's constitutional future (Scottish Government, 2007) and began a consultation exercise on the issue that has run since 2007 with a series of meetings across Scotland and online forums on constitutional change. The other parties responded by establishing a commission to investigate further devolution that recommended some changes to the powers and financing of the Scottish Parliament (Commission on Scottish Devolution 2009). Therefore the Nationalists have been successful in setting the political agenda to some extent. How this issue will actually work out in future is difficult to tell, especially as when the SNP attempts to implement its referendum pledge. Goal moderation is explicit within the government white paper. However, as yet the SNP has faced no compromise over its territorial goals and consequently no internal conflict over the issue.

Two other developments within the multi-level political setting are relevant to the SNP's brief period in office so far. First, the party has been adept at adopting a more assertive approach to intergovernmental relations towards the UK government as well as seeking alliances with the two other regional governments in the UK - the Northern Ireland executive and the Welsh Assembly Government. The SNP has been involved in discussions with the other governments and keen to re-establish the formal mechanisms for intergovernmental dialogue - the Joint Ministerial Committee - that had fallen into disuse under the previous administrations. ${ }^{\text {xix }}$ There were also joint discussions over the financial powers and functioning of the different assemblies and governments in relation to public expenditure during the recession.

Second, the triple impact of SNP success in Scotland, Labour's serious electoral difficulties in 2007-8 plus the electoral popularity of the Conservatives (in England) has given the UK dimension of multi-level elections renewed importance. In Scotland, there is the prospect of the SNP capitalising on its position and popularity to win a number of seats at the next UK election from Labour. At the 2009 European elections, the SNP took first place with $29.1 \%$ of the vote to Labour's $20.8 \%$. The SNP also achieved first place in 22 of the 32 Scottish local authority areas. In 
addition, there is the prospect of electoral change at the UK level in the near future in the shape of a Conservative government or minority administration, This development will significantly alter the SNP's political opportunity structure at both Holyrood and Westminster. Not only would the political reality of a Conservative government at Westminster transform the context for an independence referendum in 2010, but a UK minority administration or one with a slim minority would present opportunities for the SNP to extract policy concessions if it had a sizeable contingent of MPs with some bargaining power in the House of Commons. ${ }^{\mathrm{xx}}$ The interaction between the different levels of politics at the level of both government institutions and political parties would prove a testing environment for devolution and Scotland's constitutional status.

\section{Conclusion}

This paper has sought to outline the SNP's ideological development since its formation in 1934 in the context of adaptation to party system change and the onset of multi-level electoral and governmental settings. It traced the party's evolution from a non-ideological organisation to one in which a 'ruling myth' was advanced as a justification for staying away from class politics. This period gave way to one in which new members and organisational growth produced a more social democratic party, followed by a period of ideological contestation with the 79 Group after the referendum and general election of 1979. That period seems a world away from the current SNP as it appears the polar opposite to the consensual, ideology-lite (and electorally successful) Nationalist party and government currently in office - even though some of the same individuals are prominent in each period. A large number of things have changed to facilitate this situation such as the SNP's ideological convergence with Labour, Labour's own policy repositioning under New Labour, the onset of devolution, the complexities of a multi-party system in which the SNP has to compete with the right, left and centre, as well as changes in the social and partisan composition of the Scottish electorate. It should also be pointed out that the SNP is not alone in reforming its social democracy to take account of changed political and socio-economic circumstances - this is a much more general phenomenon. However, since 2007, the SNP has faced the challenge of adapting to government office, in terms of policy delivery and government performance but also - most importantly for 
a regionalist party - the impact of office success on the party's fundamental territorial goal of independence. Will government office help the SNP to deliver independence? Or, as is more common for regionalist parties in government, will it preside over staged transfers of autonomy? Either scenario will be contingent not only on its own performance in office but on the responses of the other political parties and institutions in a complex multi-level environment.

\section{References}

Bennie, L, James Mitchell and Jack Brand (1997), How Scotland Votes, Manchester: Manchester University Press.

Brand, Jack (1990), 'Scotland', in Michael Watson (Ed), Contemporary Minority Nationalism, Routledge, London.

Brand, Jack (1978), The National Movement in Scotland, London: Routledge and Kegan Paul.

Commission on Scottish Devolution (2009), Serving Scotland Better: Scotland and the United Kingdom in the $21^{\text {st }}$ Century, Edinburgh: HMSO.

Denver, David, Robert Johns, James Mitchell and Charles Pattie (2007), 'The Holyrood elections 2007: Explaining the results', paper delivered to the conference of Elections, Public opinion and Parties, University of Bristol, September 2007.

De Winter, Lieven, Marga Gomez-Reino Cachafeiro and Peter Lynch (eds) (2006), Autonomist Parties in Europe, Barcelona: ICPS.

De Winter, Lieven and Huri Türsan (eds) (1998), Regionalist Parties in Europe, London: Routledge.

Drucker, Henry (1978), Breakaway: The Scottish Labour Party, Edinburgh: Edinburgh University Student Publications Board. 
Finlay, Richard (1994), Independent and Free: Scottish Politics and the Origins of the Scottish National Party 1918-1945, Edinburgh: John Donald.

Hanham, H. J. (1969), Scottish Nationalism, London: Faber.

Hix, Simon and Christopher Lord (1997), Political Parties in the European Union, Basingstoke: Macmillan.

Kennedy, Gavin (Ed), (1976), The Radical Approach: Papers on an Independent Scotland, Palingenesis Press, Edinburgh.

Lynch, Peter (2002), SNP: The History of the Scottish National Party, Cardiff: Welsh Academic Press.

Lynch, Peter and Anwen Elias (2009), 'Devolution in the UK and the Inexorable Rise of Scottish and Welsh Nationalism?', Paper prepared for the 21st World Congress of Political Science, International Political Science Association, July 12 to 162009 , Santiago, Chile.

Maxwell, Stephen (1976), 'Beyond Social Democracy', in Gavin Kennedy (Ed), The Radical Approach: Papers on an Independent Scotland, Palingenesis Press, Edinburgh.

Miller, William (1981), The End of British Politics?: Scots and English political behaviour in the seventies, Oxford: Clarendon.

Mitchell, James (1996), Strategies for Self-government, Edinburgh: Polygon.

Mitchell, James (1990), 'Factions, Tendencies and Consensus in the SNP in the 1980s', in Alice Brown and Richard Parry (Eds), The Scottish Government Yearbook 1990, Unit for the Study of Government in Scotland, Edinburgh.

Paterson, Lindsay (2006), 'Sources of Support for the SNP', in C. Bromley, J. Curtice, K. Hinds and A. Park (Eds), Has Devolution Delivered?, Edinburgh: Edinburgh University Press.

Paterson, L., A. Brown, J. Curtice, K. Hinds, D. McCrone, A. Park, K. Sproston and P. Surridge (2001), New Scotland, New Politics?, Edinburgh: Polygon. 
Rokkan, Stein and Derek Urwin (1983), Economy, Territory, Identity. London: Sage.

Saren, Jane and James McCormick (2004), 'The Politics of Scottish Labour's Heartlands', in Gerry Hassan (Ed), The Scottish Labour Party: History, Institutions and Ideas, Edinburgh: Edinburgh University Press.

Scottish Government (2007), Choosing Scotland's Future, Edinburgh: Scottish Government.

Scottish Government (2007a), Consultation in the role of a Scottish Futures Trust in infrastructure investment in Scotland. Edinburgh: Scottish Government.

Scottish new Labour (1999), Building Scotland's Future, Glasgow: Scottish Labour Party.

SNP (2007), Manifesto 2007 - It's Time, Edinburgh: SNP.

SNP (2003), Manifesto 03 - The Complete Case for a Better Scotland, Edinburgh: SNP.

SNP (1969), Annual National Conference Agenda, $30^{\text {th }}$ May to $1^{\text {st }}$ June, Oban.

SNP (1966), SNP\& You, Glasgow, 28 p.

Ware, Alan (1996), Political Parties and Party Systems, Oxford: Oxford University Press.

Wolfe, Billy (1973), Scotland Lives, Reprographia, Edinburgh.

i. http://www.scotland.gov.uk/topics/a-national-conversation ii. http://commissiononscottishdevolution.org.uk/papers.php

iii. Resolution 2, SNP annual national conference agenda, 1975, p.4.

iv. http://www.snp.org/about/about.html

v. The Statement of Aim and Policy of the Scottish National Party, 1946, is included as an appendix in Hanham's book Scottish Nationalism, pp.213-30, which was reprinted from the Scots Independent of January 1947.

vi. This long-term factor itself is reflective of a centre-left party which looks to the state for policy solutions rather than the market.

vii. The Liberals won 7.6\% of the vote in 1964 and $6.8 \%$ in 1966 and, their seats increased from 1 in 1959 to 5 in 1966. The SNP meantime, polled 2.4\% in 1964 and then 5.5\% in 1966.

viii. Some of these members passed through the SNP to the Scottish Socialist Party from the late 1990s onwards.

ix. SNP (1969), Employment in the New Scotland, Resolution 2, annual national conference agenda, pp.4-8. 
x. For a number of years the SNP was attacked by its opponents with the claim that SNP stood for 'still no policies'.

xi. This was the Butskillite consensus named after Labour leader Hugh Gaitskill and Conservative chancellor of the Exchequer, Rab Butler: it centred around the levels of consensus between the two parties in relation to the mixed economy, NHS, housing and nationalisation. It was broken by the Conservatives briefly in the early 1970s under Heath's administration and then completely under the Thatcher administration after 1979.

xii. SNP Chairman's report, National Council, 7h December 1974.

xiii. 79 Group (1979), 79 Group papers No.1.

xiv. Alex Salmond, Democracy and Politics in the SNP, discussion paper at 79 Group conference, Glasgow, 1979.

xv. Traditionalists defeated left-wingers at the 1979 conference for key posts such as party chairman, senior vice-chairman, Executive Vice-Chairman for Policy and Executive Vice-Chairman for Organisation - defeating 79 Group members or leading members of the SNP's left.

xvi. The SNP was active in industrial campaigns in response to the closure of the Lee Jeans factory in Greenock, Robb Caledon shipyard in Dundee, Plessey and Gartcosh steel plant, in addition to undertaking a campaign of civil disobedience.

xvii. The party's pro-business image at this time was seen to have led to a drift of supporters to the Greens and SSP, though the same policy did not prevent the SNP making substantial gains from both of these parties in 2007.

xviii. Scottish National Party and Scottish Green Party Cooperation Agreement, May 2007. xix. The plenary Joint Ministerial Committee met for the first time in 6 years on 5th June 2008, to discuss financial issues and the 2010 Olympics. The Herald, 6th June 2008.

xx. The Herald, 21st April 2008. 